\title{
Raised alpha-fetoprotein levels in amniotic fluid and maternal serum associated with distension of the fetal bladder caused by
} absence of urethra

\begin{abstract}
SUMMARY Raised alpha-fetoprotein concentrations were found at 29 and 30 weeks' gestation in the amniotic fluid and maternal serum of a woman who presented in her seventh pregnancy with apparent polyhydramnios. The fetus had multiple abnormalities including gross distension of the bladder resulting from absence of the urethra, intestinal atresia, and a congenital heart defect.
\end{abstract}

Several fetal abnormalities other than neural tube defects have now been reported where the amniotic fluid alpha-fetoprotein (AFP) was increased. These include congenital nephrosis (Kjessler et al., 1975; Thom et al., 1977), oesophageal atresia (Seppala et al., 1974), duodenal atresia (Weinberg et al., 1975), omphalocele (Nevin and Armstrong, 1975), and Meckel's syndrome (Chemke et al., 1977). In the present report raised amniotic fluid and maternal serum AFP levels were associated with multiple fetal abnormalities including gross distension of the bladder caused by absence of the urethra, intestinal atresia, transposition of the aorta, and an interventricular septal defect.

\section{Case report}

This 35-year-old patient's first four pregnancies each ended in a spontaneous abortion at 12 weeks' gestation, and her fifth, a female, had transposition of the great vessels with both atrial and septal defects. There was no family history of congenital heart abnormalities; a sister-in-law died with spina bifida. Her sixth pregnancy ended in a spontaneous abortion. Throughout her seventh pregnancy there was disparity between the period of amenorrhoea and the uterine size. At 23 weeks' amenorrhoea the uterine size corresponded to 30 weeks' gestation and within 4 weeks the uterine size was equivalent to 40 weeks' gestation. An ultrasonic scan excluded twins and showed excessive fluid, $30 \mathrm{ml}$ of which was aspirated; the AFP concentration was $3.5 \mu \mathrm{g} / \mathrm{ml}$.

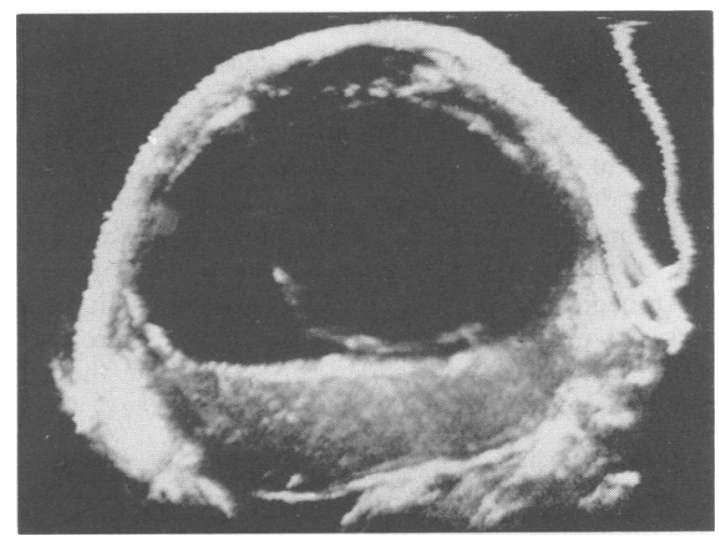

Fig. 1 Ultrasonogram at 30 weeks' gestation: transverse section $3 \mathrm{~cm}$ above umbilicus showing posterior placenta, right sided cystic area (amniotic fluid), and a larger cystic area (distended fetal bladder).

Two weeks later an ultrasonic scan showed the fetus to be pushed down into the pelvis by the excessive fluid, an appearance which was suggestive of a large loculated cystic mass. Further fluid was withdrawn; the AFP concentration was again $3.5 \mu \mathrm{g} / \mathrm{ml}$. A week later, at 30 weeks' gestation, the ultrasonic scan clearly indicated a large cystic area occupying most of the uterine cavity separated by a septum from a smaller area of fluid in the right upper quadrant of the uterus with the fetal head compressed into the pelvis and the body in the right lower quadrant of the uterus (Fig. 1). Fluid was withdrawn from both areas; the AFP concentrations were $3.3 \mu \mathrm{g} / \mathrm{ml}$ and $72.0 \mu \mathrm{g} / \mathrm{ml}$ in the larger and smaller areas respectively (Table). The fluid from the smaller area was undoubtedly amniotic fluid having a total protein content of $10 \mathrm{~g} / \mathrm{l}$, albumin 6 $\mathrm{g} / \mathrm{l}$, and bilirubin $10 \mu \mathrm{mol} / \mathrm{l}$, and also fetal cells. The fluid from the larger area contained no fetal cells and had a total protein content of $3 \mathrm{~g} / 1$, albumin $1 \mathrm{~g} / 1$, and no bilirubin. Thus this large cystic area was considered possibly to be an intrauterine cyst. 
The next day when the patient went into spontaneous labour, the uterus was observed contacting and the round ligaments were easily palpated during a contraction. Full dilatation was quickly reached.

Table Alpha-fetoprotein in amniotic fluid, fetal urine and maternal serum

\begin{tabular}{|c|c|c|c|}
\hline \multirow[t]{2}{*}{$\begin{array}{l}\text { Gestation } \\
(w)\end{array}$} & \multicolumn{2}{|c|}{$\begin{array}{l}\text { Alpha-fetoprotein } \\
(\mu \mathrm{g} / \mathrm{ml})\end{array}$} & \multirow[t]{2}{*}{$\begin{array}{l}\text { Maternal serum } \\
\text { AFP }(\mathrm{ng} / \mathrm{ml})\end{array}$} \\
\hline & Fetal urine* & Amniotic fluid & \\
\hline $\begin{array}{l}27 \\
29 \\
30\end{array}$ & $\begin{array}{l}3 \cdot 5 \\
3 \cdot 5 \\
3 \cdot 3\end{array}$ & $\begin{array}{l}- \\
72 \cdot 0(1.4 ; 2.9)\end{array}$ & $\begin{array}{l}- \\
680(380 ; 630) \\
680(400 ; 640)\end{array}$ \\
\hline
\end{tabular}

Figures in parentheses show values of normal mean and 95th centile. * Normal fetal urine AFP range 0.1 to $3.4 \mu \mathrm{g} / \mathrm{ml}$ (Weiss et al., 1976).

During an attempted forcep delivery, the head separated from the trunk. It was apparent now that the appearance of polyhydramnios was the result of gross distension of the fetal abdomen. Decompression of the fetal abdomen was carried out with the removal of more than 2 litres of fluid. The trunk was delivered by internal version and breech extraction.

At necropsy, the abdominal distension which has persisted even after decompression resulted from an enormously enlarged bladder into which one (the left) dilated ureter entered (Fig. 2). The only kidney, which

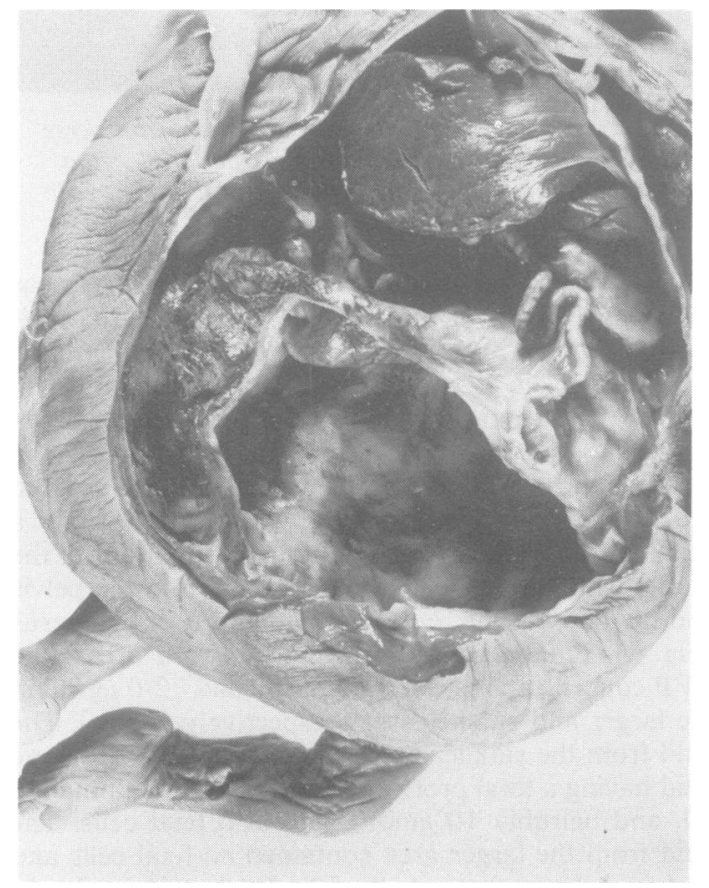

Fig. 2 Necropsy appearance showing grossly distended bladder, and bowel ending blindly behind the bladder. was hydronephrotic, lay slightly to the left of the midline in the upper abdomen. Behind the dilate bladder only one ovary and tube were present. There was no urethra and only a clitoris was identifiable. The small bowel which was of small calibre throughout measured $89.5 \mathrm{~cm}$, with meconium only in the terminal portion. The large bowel which measured only $17 \mathrm{~cm}$ was also much contracted with a narrovo lumen and ended in a blind mucus filled sac toward\$ิ the apex of the bladder. There was no anal canal. The oesophagus, stomach, and pancreas were normal. The $\overrightarrow{0}$ heart showed a patent foramen ovale, an aorta transposed arising entirely from the right ventricle, hypoplastic pulmonary artery ending in a blind sae within the interventricular musculature, dividing into small right and left pulmonary arteries and joined to the aorta by a patent ductus. Pulmonary veins entered the left atrium. An interventricular septal defect (pars? membranacea) was also present.

\section{Discussion}

In open fetal neural tube defects the origin of the increased amniotic fluid AFP is considered to be leakage of the protein from fetal serum and cerebro $\overrightarrow{0}$ spinal fluid. This hypothesis is supported by the findings of high AFP levels in fetal serum and fetal cerebrospinal fluid between 15 and 20 weeks' gestation and also by normal amniotic AFP levels in fetas neural tube defects covered by a full thickness of skino (Brock, 1976). It has also been suggested that theo raised amniotic fluid AFP may be the result of feta呑 serum transudation rather than a leakage into the $\overrightarrow{0}$ amniotic fluid (Weiss et al., 1976).

In fetal abnormalities other than open neural tube defects, several different mechanisms have been postulated for the raised amniotic fluid AFP. In congenital nephrosis with a fetal proteinuria, raisedo amniotic fluid AFP has been observed (Kjessler et al. 0 1975; Thom et al., 1977). Recently, Chemke et al (1977) have reported Meckel's syndrome without aô neural tube defect in which the raised amniotic fluid ${ }^{\beta}$ AFP was attributed to polycystic kidneys. In gastro-o intestinal abnormalities, the raised amniotic fluid $\mathrm{AFP}_{\supset}$ is probably through disturbed or absent fetal swallow-o ing (Weinberg et al., 1975). Intestinal atresia may disturb the normal passage of amniotic fluid througho the fetal gut thus preventing normal absorption and/or 0 degradation.

In our patient, the appearance of polyhydramnios was the result of distinct enlargement of the fetal abdomen caused by distension of the fetal bladder? resulting from absence of the urethra. The fluidos obtained transabdominally at 27,29 , and 30 weeks' gestation was fetal urine with AFP levels within ${ }_{0}^{-}$ previously reported normal ranges (Table). As fetal 
urine is a major source of amniotic fluid AFP, urethral obstruction alone would result in a low amniotic AFP level, as in disorders associated with renal dysgenesis. The raised amniotic fluid and maternal serum AFP is most probably caused by regurgitation of bile and gastric contents into the amniotic fluid due to intestinal atresia. Transudation of fetal serum as a result of the gross abdominal distension is unlikely. In omphaloceles with exposure of blood vessels, easy transudation of fetal serum will result in increased amniotic fluid AFP (Nevin and Armstrong, 1975; Weiss et al., 1976), but when the exomphalos is covered with skin amniotic fluid AFP is normal.

Fortunately, in most instances where a high AFP level has been found in the absence of a neural tube defect, the fetal abnormalities have been so serious as not to compromise the validity of termination of the pregnancy because of the high AFP value.

\section{N. C. Nevin, A. Ritchie, F. McKeown, AND G. ROBERTS}

Departments of Medical Genetics, of Midwifery and Gynaecology, and of Pathology, Institute of Clinical Science, The Queen's University of Belfast, and the Department of Biochemistry, The Royal Victoria Hospital, Belfast, Northern Ireland

\section{References}

Brock, D. J. H. (1976) a-fetoprotein and the prenatal diagnosis of central nervous system disorders. Child's Brain, 2, 1-23.

Chemke, J., Miskin, A., Rav-Acha, Z., Porath, A., Sagiv, M., and Katz, Z. (1977). Prenatal diagnosis of Meckel syndrome: alphafetoprotein and beta-trace protein in amniotic fluid. Clinical Genetics, 11, 285-289.

Kjessler, B., Johansson, S. G. O., Sherman, M., Gustavson, K. H., and Hultquist, G. (1975). Alphafetoprotein in antenatal diagnosis of congenital nephrosis. Lancet, 1, 432-433.

Nevin, N. C., and Armstrong, M. J. (1975). Raised alphafetoprotein levels in amniotic fluid and materal serum in a triplet pregnancy in which one fetus had an omphalocele. British Journal of Obstetrics and Gynecology, 82, 826-828.

Seppala, M., Laes, E., and Harvo-Noponen, M. (1974). Elevated amniotic fluid alpha-fetoprotein in congenital oesophageal atresia. Journal of Obstetrics and Gynaecology of the British Commonwealth, 81, 827-828.

Thom, H., Johnstone, F. D., Gibson, J. I., Scott, G. B., and Noble, D. W. (1977). Fetal proteinuria in diagnosis of congenital nephrosis detected by raised alpha-fetoprotein in maternal serum. British Medical Journal, 1, 16-18.

Weinberg, A. G., Milunsky, A., and Harrod, M. J. (1975). Elevated amniotic fluid alpha-fetoprotein and duodenal atresia, Lancet, 2. 496.

Weiss, R. R., Maori, J. N., and Elligers, K. W. (1976). Origin of ammiotic fluid alpha-fetoprotein in normal and defective pregnancies. Obstetrics and Gynecology, 47, 697-700.

Requests for reprints to Dr N. C. Nevin, Department of Medical Genetics, The Queen's University of Belfast, Institute of Clinical Science, Grosvenor Road, Belfast BT 12 6BJ.

\section{Primary hypogonadism in the Borjeson-Forssman-Lehmann syndrome}

SUMMARY A 28-year-old man with mental retardation and multiple congenital malformations was found to have the classical features of Borjeson-Forssman-Lehmann syndrome. Endocrine evaluations showed primary hypogonadism as the underlying endocrine abnormality rather than hypopituitarism as suggested in earlier reports.

Borjeson et al. $(1962,1963)$ described 3 related males with an X-linked recessive syndrome characterised by profound mental retardation, microcephaly, peculiar fatty facies, and hypogonadism. Findings in an isolated case (Baar and Galindo, 1965) and in one of the original patients (Brun et al., 1973) suggested hypopituitarism as the basic endocrine abnormality.

We report here the clinical and endocrine findings in an individual with this syndrome.

\section{Case report}

The patient is a 28-year-old man who has resided in an institution for the retarded since age 11 . Information on his past history is scanty as we have been unsuccessful in reaching any of his relatives. According to the records, there are no similar cases or mental retardation in the family. He was born with a weight of $2.6 \mathrm{~kg}$ to a 15 -year-old primigravida. Bilateral inguinal herniorrhaphies were performed at age 3 months, but the operative reports are not available. He sat unsupported at 3 years of age, stood alone at $3 \frac{1}{2}$ years, and walked at 4 years. By 4 years of age he was capable of some speech, but this has remained limited to the utterance of several phrases.

When admitted to the institution at age 11 years, his height was $127 \mathrm{~cm}$ (50th centile for 8 years) and his weight, $27.4 \mathrm{~kg}$, was 5 th centile for age. Major motor seizures occurred three times in the next seven years and at age 18, sodium pentobarbitone was prescribed intermittently because of increased frequency of seizures. Diphenylhydantoin, $32 \mathrm{mg}$ orally, t.i.d., was started at age 20 and has been given regularly to this time. Seizures have been adequately controlled since age 23 when primidone, $100 \mathrm{mg}$, t.i.d. was added to this therapeutic regimen.

He has been admitted to hospital with cellulitis of the lower extremities on several occasions. Recurrent otitis media with bilateral tympanic membrane perforations necessitated a tympanoplasty at age 23 . His 